\title{
Opinions and Attitudes of Prospective Teachers for the Use of Mobile Phones in Foreign Language Learning
}

\author{
Ismail Cakir \\ Erciyes University, Turkey
}

\begin{abstract}
The aim of this study is to explore the current use of mobile phones in a foreign language teaching context where Engish is used as the medium of instruction by prospective teachers. To this end, it presents the views of prospective English teachers on utilizing the mobile phone as an instructional tool for foreign language learning purposes in the educational and instructional setting of foreign language teaching classrooms. The study utilized a quantitative methodology. In this context, a questionnaire was developed and administered to a sample of 193 participants in an English Language Teaching (ELT) department. The data gathered through the questionnaire were processed and analyzed descriptively. Results indicate that most of the participants would prefer to use mobile phones as instructional tools in foreign language learning. The results also provided some insights as to how foreign language teachers could employ suitable approaches to make learning and teaching English meaningful and communicative. The results suggested that the participants would like to make use of mobile phones for educational purposes when they become teachers of English. It is recommended that some of technology-based language teaching activities can be implemented using mobile phones and they can be integrated into foreign language teaching curriculum.
\end{abstract}

Keywords: Foreign language learning; Learner autonomy; m-learning; Mobile assisted learning; Prospective teachers.

\section{Introduction}

The inevitable advance of technology has had a great influence on people's daily lives. Thus, people often feel obliged to be bound by technology in every aspect of their daily routines as it makes their lives easier (Oelofse, 2008). Recently, devices such as mobile phones and MP3 players have grown to such an extent over recent years and thus are gradually replacing personal computers in modern professional and social contexts (Attewell \& Savill-Smith, 2005). Correspondingly, a great amount of teachers nowadays face young students who are generally more skillful in using technological devices such as an MP3 player, a laptop, a game station and so on. Besides, these digital natives are surrounded with technological gadgets which keep on changing at a very fast rate (Bayne \& Ross, 2007; Bester \& Brand, 2013). Furthermore, being technologically friendly and digitally fluent, younger generations spend most of their time on these devices for socializing or entertainment (Ally, 2009).

Considering the fact that students in the classroom are called 'digital natives' (Prensky, 2007) or the 'net generation' (Oblinger, 2003), technology has become an integral part of education in many ways. In this respect, teachers and, more specifically, students have a great tendency towards the use of technological devices and facilities in the classroom because they greatly 
aid learning. Within this context, Reinders and Cho (2010) contend that any tool that can increase students' access to the language will contribute greatly to their progress.

Being an indispensible component of students' daily life, technology is expected to serve pedagogically useful functions in education. Therefore, it is necessary to incorporate these technologies into the school curriculum. As foreign language learners would benefit from using technology, in particular mobile phones, this study intends to investigate the attitudes and expectations of the prospective teachers studying English as their major.

\section{Mobile Assisted Learning}

Mobile learning, or m-learning, can be defined as any form of learning that happens when mediated through mobile devices; a form of learning that established the legitimacy of 'nomadic' learners (Alexander, 2004). M-learning is the facilitation of learning and access to educational materials for students using mobile devices via a wireless medium (Litchfield, Dyson, Lawrence, \& Zmijewska, 2007, p.589). This type of learning is commonly associated with the use of mobile technology, especially the mobile phone (Cavus, Bicen \& Akcil, 2008; Naismith, Lonsdale, Vavoula, \& Sharples, 2004). Although mobile phones are one technology that has started to draw particular attention from educators, some other techological devices are also available, such as wireless laptop computers, portable MP3 players, personal digital assistants (PDAs), electronic dictionaries and so on (Stockwell, 2010).

For Odabasi (2009), mobile learning is an education model that emerged as a consequence of the development of mobile technologies. It is the process of using a mobile device to access and study learning materials in order to communicate with fellow students, instructors or institutions (Ally, 2009). Acarturk (2012) argues that the use of mobile devices has become more common in many areas of daily life than in previous years, and technologies like e-books have begun to replace printed materials. For Tai and Ting (2011), the adoption of technology in language learning has advanced from Computer Assisted Language Learning (CALL) to Mobile Assisted Language Learning (MALL). MALL has prominently transformed language teaching and learning (Cui \& Wang, 2008; Kilickaya, 2009; Kukulska-Hulme, 2009; Kukulska-Hulme \& Shield, 2008). With better accessibility and practicability, mobile devices have become a delivery channel of great potential for sustainable learning (Khanna \& Singh, 2011). Simply put, MALL has had a considerable effect on instruction in foreign language teaching classrooms.

From the foreign language teaching perspective, the mobile technology offers various opportunities for learners and teachers. Geddes (2004) postulates that MALL affords second or foreign language learners and teachers ever greater opportunity to practice the target language "anywhere and anytime". Learners are used to working with mobile devices, often more so than with computers. With MALL, students are able to access language learning materials, and to communicate with their teachers and peers at any time, anywhere (KukulskaHulme \&Shield, 2006). MALL is relevant to an interactive learning environment, increases potential for distributed practice, and is suitable for encouraging classroom interactivity (Levy \& Kennedy, 2005). It is true to state that utilizing technological devices in the classroom creates a student-centered approach, and encourages positive attitudes amongst students regarding the language learning process (Akbulut, 2008; Basoglu \& Akdemir, 2010; Markett, et al., 2006; Saran, Cagiltay \& Seferoglu, 2007; 2008; Sengel et al.,2014). Additionally, active learning environments and authentic learning environments in the classroom can be 
promoted. In this sense, Thornton and Houser (2005) considers technology to be an aid to extend learner opportunities in meaningful ways.

\section{MALL in Foreign Language Teaching}

Hussein and Cronje (2010) have asserted that mobile devices are revolutionary because they transcend the boundaries of the structural status of classrooms and lecture halls and their associated modes of communication. They do not have to be confined to one particular place in order to be effective. Particularly, mobile phones that younger generations use for multiple purposes offer many functionalities that can be utilized in the classroom. M-learning, or elearning, facilitates students' access to educational materials and contributes to their learning in wireless environments (Litchfield, Dyson, Lawrence, \& Zmijewska, 2007; Mayisela, 2013). Tai and Ting (2011) highlight that when a mobile technology or device becomes popular, then it is worth exploring possible applications for language learning. Some studies have been conducted regarding the instruction of foreign language teaching components such as listening, reading, writing, idioms, vocabulary, and pronunciation (Chen \& Chung 2008; Lu, 2008; Ducate \& Lomicka, 2009; Edirisingha, Rizzi, Nie, \& Rothwell, 2007; Thornton \& Houser, 2005).

Mobile phones offer functions including SMS, voice-messaging, MMS, internet access, video recording, voice recording, MP3/MP4 player, digital camera, and access to social networking platforms such as Facebook, Twitter, WhatsApp etc. Given these functionalities, it can be asserted that it is possible to utilize them for educational purposes. In particular, in the foreign language teaching context some of these functions can be utilized to teach or practice activities in the classroom. The SMS tool can be used to send out vocabulary items (Thornton \& Houser, 2005), and to administer quizzes (Saran \& Seferoglu, 2010). Through the Internet access that many mobile phones offer, foreign language learners can easily access the Internet and reach sources such as dictionaries, articles etc. immediately.

Additionally, it can be asserted that it is possible to access language resources anywhere and anytime via mobile phones. To this end, foreign language learners can be exposed to the challenges of foreign language learning such as comprehensible input (Krashen, 1985), which might not always be possible in many foreign language contexts. Simply put, mobile phones may offer a motivating alternative for second language (L2) learning (Al Aemri, 2011). In particular, teachers need to expect learners to use their mobile phones since they own and already use them outside the classroom.

Many of the articles regarding mobile learning have focused on using mobile devices for educational purposes. Some of them have been concerned with students' attitudes towards and challenges with mobile phones in language learning. Studies conducted on mobile phones sought the reactions of $\mathrm{m}$-learning and integration into the classroom (Burston, 2011; Cavus \& Uzunboylu, 2009; Hung, Hwang, Su \& Lin, 2012; Keskin \& Metcalf, 2011; Kiernan\& Aizawa, 2004; Kuzu, Cuhadar, \& Akbulut, 2007; Wang, Shen, Novak \& Pan, 2009; Wu et al., 2012; Zhang, Song, \& Burston, 2011). The research has shown that the studies based on the use of mobile SMS for learning English encouraged classroom interactions, motivated students to learn English, promoted vocabulary acquisition and tested their progress (Esit, 2011; Markett et al., 2006; Meurant, 2007; Saran \& Seferoglu, 2010; So, 2009; Song \& Fox, 2005). 
In this context, Attewell (2005) conducted research with participants from three countries. She designed an SMS-based course in order to motivate learners to study foreign language. The results displayed that the students had great improvement in reading comprehension and increased motivation towards the target language.

In the research carried out with university students by Cakir (2011), most of the participants who had the opportunity to use mobile education tools stated that they were interested in mobile learning environments and wanted to make use of mobile learning technologies if given the opportunity. Uzunboylu and Ozdamli (2011) carried out research to illustrate attitudes towards technology-based cooperative learning. They found that the participants developed significantly positive attitudes towards technology at the end of the experiment.

In the study that Thornton and Houser (2005) carried out with Japanese foreign language learners, they investigated the use of mobile phone functionalities for educational purposes, such as e-mail exchange, receiving vocabulary lessons, and using video-capable mobile phones for explaining English idioms. The results revealed that participants viewed mobile phones as a valuable instructional tool, and they evaluated it as educationally effective. Saran, Cagiltay and Seferoglu's (2008) found that the use of mobile phones had a positive effect on language learning. Similarly, Cavus and ibrahim (2009) explored the use of mobile phone in learning English vocabulary using Short Message Service (SMS) text messaging. The participants stated that they were delighted to learn new words via mobile phones. In the same vein, McConotha, Praul and Lynch (2008) conducted a study on the use of mobile devices in the learning process, which proved that students achieved higher scores while they were reviewing and practicing for the exams. In their research, Nah, White and Sussex (2008) also found that the students expressed positive attitudes to these activities; students found the activities offered by the mobile phone to be convenient and interactive.

Basoglu and Akdemir (2010) conducted another study with 60 university students; they compared the effects of mobile phones on vocabulary learning with that of flashcards. The results generally indicated that the participants' attitudes toward learning English vocabulary positively changed. In their study, Zhang, Song, and Burston (2011) obtained similar positive reactions.

\section{Research Questions}

As seen, from the research cited above, general tendency is based on the efficacy of mobile technology and mobile phones in foreign language learning context. Therefore, with this study it is intended that the findings of the attitudes and expectations of the prospective English Language Teaching (ELT) teachers towards the use of mobile learning will contribute to field. In this context, the present study attempted to find answers for the following research questions.

1. How do prospective ELT teachers use mobile phones for foreign language learning purposes in and outside the classroom?

2. What are the participants' attitudes towards using mobile phones in the classroom?

3. Is there a statistical difference between the males and females in terms of utilizing mobile phones in foreign language learning? 


\section{Method and Material}

This study utilized a quantitative research method in which the data was gathered through the questionnaire. Questionnaire is one of the key features of the survey research. As Gall, Gall, and Borg (2003) state, researchers often use questionnaires and interviews extensively in educatucational research to collect data that are not directly observable: inner experience, opinions, values and interests.

\section{Participants}

The sample of this study consisted of 193 prospective English teachers at different grades of the ELT department. The reason for selecting this sample was of being convenience because they were accessible to the researcher (Friedman, 2012, p.186). The participants attended the study on a voluntary basis. Demographically, of the participants, 40 (20.7\%) were male and 153 (79.3\%) were female.

\section{Data Collection}

In order to figure out the current position of mobile phone use of prospective English teachers both in and out of the classroom, a survey was devised by the researcher and was used to conduct this study. In the research, the participants' attitudes and opinions towards using mobile phone as an instructional tool for foreign language learning was investigated.

The questionnaire was composed of ten questions, two of which were designed in a threepoint Likert scale. Eight of the questions in the survey were designed in a semi-structured format. The first question aimed to determine the participants' gender, and the second question aimed to find out whether the participants own a mobile phone. The third research question in the survey used a three-point Likert-scale with "never", "sometimes" and "often" choices to find out the purposes of mobile phone usage among the participants. The fourth question asked if the participants used mobile phones for language learning; the fifth question sought responses to the question "How often do you use your mobile phone for English language learning?" Respondents were also asked whether they had ever written and sent a text message in English via mobile phone. As in the third question, the seventh question was also designed in the three-point Likert-scale format with "never", "sometimes" and "often" choices to specify the activities carried out with mobile phones. The survey also included a question that aimed to express how much support they got from their teachers for the accomadation of mobile phones in their foreign language teaching classrooms. In the ninth and tenth questions of the survey the participants were asked if they believed that mobile phones would aid them in completing schoolwork, and their views on the usage of mobile phone as a learning tool in their future professional carreer.

Before administering the survey, it was checked by three colleagues for its face and content validity. The finalized items were checked by a group of participants $(n=30)$. Depending on the feedback form the participants some of the items were revised with respect to language aspect. Furthermore, the participants were informed about the aim of the survey and they voluntarily responded to the questions. 


\section{Statistical Analysis}

In order to identify the perceptions, attitudes, and views of the participants, the data obtained through the survey was analyzed quantitatively using SPSS 16.0 program. In this descriptive analysis, while determining the aims of mobile phone use of the participants, more specifically gender types, frequency and percentage have been used. Chi-Square $\left(\mathrm{X}^{2}\right)$ analysis was used to analyze the purposes of mobile phone usage among the participants based on the teacher's encouragement and the participants' gender types. The significance level was set as 0.05 .

\section{Results}

The results obtained through the survey are presented and discussed based on the research questions. First, the extent to which mobile phones are used both in and outside the classroom is analyzed. Secondly, the frequencies of the activities that the participants carried out on mobile phones is displayed. Thirdly, the types of activities that the participants used for language learning is presented. In the sixth and seventh tables, encouragement of mobile phone usage that the respondents got from their lecturers, and the participants' belief about the efficacy of mobile phone in learning the target language is reported. Finally, prospective English teachers' prospenity for mobile phone use in their future professional lifer is reported and discussed.

Table 1. Results Related to the Purpose of Using of Mobile Phones

\begin{tabular}{llll}
\hline Questions & Responses & $\mathbf{f}$ & $\%$ \\
\hline Do you use mobile phone to communicate? & Yes & 190 & 98.4 \\
& No & 3 & 1.6 \\
Do you currently use mobile phone in your language & Yes & 113 & 58.5 \\
learning education? & No & 80 & 41.5 \\
& Hardly ever & 16 & 14.2 \\
How often do you use your mobile phone for English & A few times a week & 59 & 52.2 \\
language learning? & Every day & 22 & 19.5 \\
& A few times a day & 16 & 14.2 \\
Have you ever written and sent a text message in & Yes & 154 & 79.8 \\
English? & No & 39 & 20.2 \\
\hline
\end{tabular}

As Table 1 indicates, the majority of the participants (98.4\%) reported that they used a mobile phone as a communication tool, and only $1.6 \%$ of them expressed that they did not prefer mobile phones to communicate. When asked if they currently use mobile phones in language learning, more than half of them (58.5\%) gave a positive response. To validate this result, more than half of the participants who stated "Yes" (52.5\%) used mobile phones a few times a week for the purpose of language learning. $79.8 \%$ of the participants attested that they sent text messages in English. However, the percentage of those who wrote and sent a text message in English is $20.2 \%$. In general, it is obvious that a great majority of the participants ( $n=154)$ used mobile phones to send text messages in English, which is consistent with the findings that Levy and Kennedy (2005) found in their research. 
Table 2. The Frequency of Activities Participants Carry Out via Mobile Phone

\begin{tabular}{|c|c|c|c|c|c|c|c|}
\hline \multicolumn{2}{|c|}{ Activities } & \multicolumn{2}{|c|}{ Never } & \multicolumn{2}{|c|}{ Sometimes } & \multicolumn{2}{|c|}{ Often } \\
\hline & & \multirow{2}{*}{$\begin{array}{c}\mathbf{n} \\
12\end{array}$} & \multirow{2}{*}{$\begin{array}{l}\% \\
6.2\end{array}$} & \multirow{2}{*}{$\begin{array}{r}\mathbf{n} \\
55\end{array}$} & \multirow{2}{*}{$\begin{array}{l}\% \\
28.5 \\
\end{array}$} & \multirow{2}{*}{$\begin{array}{l}\mathbf{n} \\
126\end{array}$} & \multirow{2}{*}{$\begin{array}{l}\% \\
65.3 \\
\end{array}$} \\
\hline 1 & Sending SMS & & & & & & \\
\hline 2 & Sending e-mail & 83 & 43.0 & 86 & 44.6 & 24 & 12.4 \\
\hline 3 & Taking photos & 17 & 8.8 & 115 & 59.6 & 61 & 31.6 \\
\hline 4 & Making phone calls & - & - & 56 & 29 & 137 & 71 \\
\hline 5 & Surfing the internet & 44 & 22.8 & 76 & 39.4 & 73 & 37.8 \\
\hline 6 & Checking e-mail & 74 & 38.3 & 76 & 39.4 & 43 & 22.3 \\
\hline 7 & Recording voice & 86 & 44.6 & 88 & 45.6 & 19 & 9.8 \\
\hline 8 & Listening to music & 17 & 8.8 & 65 & 33.7 & 111 & 57.5 \\
\hline 9 & Sending MMS & 103 & 53.4 & 74 & 38.3 & 15 & 7.8 \\
\hline
\end{tabular}

The participants were requested to answer how often they carried out the activities in Table 2 via mobile phone and the responses were displayed in detail. Unsurprisingly, it is seen that SMS $(n=126)$ and making phone calls $(n=137)$ are utilized most "often" among the activities carried out by the participants. On the other hand, functionalities of recording voice $(n=86)$, sending e-mail $(n=83)$ and checking mail $(n=74)$ are "never" utilized by the participants. The reason for this may be explained by the inconvenience of the kinds of mobile phones that the participants own. Based upon the same questions, Table 3 aimed to analyze the activities by gender.

The survey sought the types of activities that the participants carried out on mobile phones. One of the activities that the research aimed to determine was to what extent mobile phones were used to send e-mail. It is clearly seen in Table 3 that $69.3 \%$ of female participants "often" used mobile phones to send SMS while 50\% male students "often" sent SMS through mobile phones. Almost $45 \%$ of the participants "sometimes" used it to send e-mail. On the other hand, the results showed that $43.1 \%$ of the female students and $43.5 \%$ of the male students 'never' used mobile phones to send e-mail. The reason for not being able to send e-mail through mobile phones, as specified above, might stem from not being able to access the internet.

Based on the results presented in Table 3, it can be stated that the participants "sometimes" prefered mobile phones to take photos (Female $=58.8 \%$; Male $=62.5 \%$ ). When asked the participants how often they used mobile phones to make phone calls, they responded as "often" (Female=72.5\%; Male=65\%); "sometimes" (40.5\%), and "often" 36.6\%. Needless to say, nowadays a great number of students are able to connect to internet on mobile phones. In this vein, the participants were asked how often they surfed the Internet. Less than $40 \%$ of the female participants, who probably have internet connection ability, surf the internet. Of the male participants, $35 \%$ "sometimes" surf on the net while $42.5 \%$ of the male students access the net through mobile phones. Those who could access the internet reported that they checked their e-mails through mobile phones. The results reveal that nearly $22 \%$ of the participants checked e-mails on their mobile phones. 
Table 3. The Frequency of the Activities Carried Out on Mobile Phones by Gender

\begin{tabular}{|c|c|c|c|c|c|c|c|}
\hline Activity & Gender & $\begin{array}{c}\text { Descriptive } \\
\text { Statistics (DS) }\end{array}$ & Never & Sometimes & Often & Total & $\begin{array}{c}\text { Chi- } \\
\text { Square }\end{array}$ \\
\hline \multirow{4}{*}{1} & \multirow[t]{2}{*}{ Female } & $f$ & 10 & 37 & 106 & 153 & \multirow{4}{*}{$\begin{array}{l}X^{2}=6.78 \\
d f=2 \\
p=.034\end{array}$} \\
\hline & & $\%$ & 6.5 & 24.2 & 69.3 & 100.0 & \\
\hline & \multirow[t]{2}{*}{ Male } & $f$ & 2 & 18 & 20 & 40 & \\
\hline & & $\%$ & 5.0 & 45.0 & 50.0 & 100,0 & \\
\hline \multirow{4}{*}{2} & \multirow[t]{2}{*}{ Female } & $f$ & 66 & 68 & 19 & 153 & \multirow{4}{*}{$\begin{array}{l}X^{2}=.005 \\
d f=2 \\
p=.997\end{array}$} \\
\hline & & $\%$ & 43.1 & 44.4 & 12.4 & 100.0 & \\
\hline & \multirow[t]{2}{*}{ Male } & $f$ & 17 & 18 & 5 & 40 & \\
\hline & & $\%$ & 42.5 & 45.0 & 12.5 & 100.0 & \\
\hline \multirow{4}{*}{3} & \multirow[t]{2}{*}{ Female } & $f$ & 13 & 90 & 50 & 153 & \multirow{4}{*}{$\begin{array}{l}\mathrm{X}^{2}=.422 \\
\mathrm{df}=2 \\
\mathrm{p}=.810\end{array}$} \\
\hline & & $\%$ & 8.5 & 58.8 & 32.7 & 100.0 & \\
\hline & \multirow[t]{2}{*}{ Male } & $f$ & 4 & 25 & 11 & 40 & \\
\hline & & $\%$ & 10.0 & 62.5 & 27.5 & 100.0 & \\
\hline \multirow{4}{*}{4} & \multirow[t]{2}{*}{ Female } & $f$ & 3 & 39 & 111 & 153 & \multirow{4}{*}{$\begin{array}{l}\mathrm{X}^{2}=.877 \\
\mathrm{df}=2 \\
\mathrm{p}=.645\end{array}$} \\
\hline & & $\%$ & 2,0 & 25.5 & 72.5 & 100.0 & \\
\hline & \multirow[t]{2}{*}{ Male } & $f$ & 1 & 13 & 26 & 40 & \\
\hline & & $\%$ & 2.5 & 32.5 & 65.0 & 100.0 & \\
\hline \multirow{4}{*}{5} & \multirow[t]{2}{*}{ Female } & $f$ & 35 & 62 & 56 & 153 & \multirow{4}{*}{$\begin{array}{l}X^{2}=.539 \\
d f=2 \\
p=.764\end{array}$} \\
\hline & & $\%$ & 22.9 & 40.5 & 36.6 & 100.0 & \\
\hline & \multirow[t]{2}{*}{ Male } & $f$ & 9 & 14 & 17 & 40 & \\
\hline & & $\%$ & 22.5 & 35.0 & 42.5 & 100.0 & \\
\hline \multirow{4}{*}{6} & \multirow[t]{2}{*}{ Female } & $f$ & 59 & 60 & 34 & 153 & \multirow{4}{*}{$\begin{array}{l}\mathrm{X}^{2}=.015 \\
\mathrm{df}=2 \\
\mathrm{p}=.992\end{array}$} \\
\hline & & $\%$ & 38.6 & 39.2 & 22.2 & 100.0 & \\
\hline & \multirow[t]{2}{*}{ Male } & $f$ & 15 & 16 & 9 & 40 & \\
\hline & & $\%$ & 37.5 & 40.0 & 22.5 & 100.0 & \\
\hline \multirow[t]{4}{*}{7} & \multirow[t]{2}{*}{ Female } & $f$ & 62 & 74 & 17 & 153 & \multirow{4}{*}{$\begin{array}{l}x^{2}=5.14 \\
d f=2 \\
p=.076\end{array}$} \\
\hline & & $\%$ & 40.5 & 48.4 & 11.1 & 100.0 & \\
\hline & Male & $f$ & 24 & 14 & 2 & 40 & \\
\hline & & $\%$ & 60.0 & 35.0 & 5.0 & 100.0 & \\
\hline & Female & $f$ & 14 & 50 & 89 & 153 & \\
\hline 8 & & $\%$ & 9.2 & 32.7 & 58.2 & 100.0 & $\mathrm{X}^{2}=.372$ \\
\hline & Male & $f$ & 3 & 15 & 22 & 40 & $d f=2$ \\
\hline & & $\%$ & 7.5 & 37.5 & 55.0 & 100.0 & \\
\hline & Female & $f$ & 82 & 59 & 12 & 153 & \\
\hline 9 & & $\%$ & 53.6 & 38.6 & 7.8 & 100.0 & $\mathrm{X}^{2}=.026$ \\
\hline & Male & $f$ & 22 & 15 & 3 & 40 & $d f=2$ \\
\hline & & $\%$ & 55.0 & 37.5 & 7.5 & 100.0 & $\mathrm{p}=.987$ \\
\hline
\end{tabular}

Recording voice on the mobile phone was not used so much by the participants (Often: Female $=11.1 \%$; Male= 5\%). However, more than $55 \%$ of the participants (Female $=58.2 \%$; Male $=55 \%$ ) 'often' listened to music on their mobile phones. Sending MMS through mobile phones were not "often" carried out by the participants (Female $=7.8 \%$; Male $=7.5 \%$ ). Based on the results in Table 3, it can be concluded that the activities that were most frequently carried out by the participants are sending SMS, making phone calls, and listening to music on the mobile phones. There is a statistically significant difference between male and female participants $(p<0.05)$ among those who 'often' sent SMS messages via mobile phones. In the other activities, it is not possible to observe a statistically significant difference between male and female participants $(p>0.05)$. 
Table 4. Activities Carried Out on Mobile Phone for Language Learning Purposes

\begin{tabular}{|l|l|c|l|l|l|l|l|}
\hline \multicolumn{2}{|l}{ Activities } & \multicolumn{2}{l|}{ Never } & \multicolumn{2}{l|}{ Sometimes } & \multicolumn{2}{l|}{ Often } \\
\cline { 3 - 9 } \multicolumn{2}{|l|}{} & $\mathbf{n}$ & $\%$ & $\mathbf{n}$ & $\%$ & $\mathbf{n}$ & $\%$ \\
\hline 1. & Using as a dictionary & 63 & 32.6 & 68 & 35.2 & 62 & 32.1 \\
\hline 2. & Listening to authentic audio materials & 73 & 37.8 & 98 & 50.8 & 22 & 11.4 \\
\hline 3. & Checking for pronunciation & 74 & 38.3 & 83 & 43 & 36 & 18.7 \\
\hline 4. & Downloading some ELT resources & 105 & 54.4 & 74 & 38.3 & 14 & 7.3 \\
\hline 5. & Surfing on the net to find information & 53 & 27.5 & 86 & 44.6 & 54 & 28 \\
\hline
\end{tabular}

In order to display to what extent the participants used mobile phones for educational purposes, particulary as an aid to learn or practice the target language, the items in Table 4 were researched within the framework of the survey. The findings attained proved that the participants, in general, had a tendency to utilize this device for educational purposes. It is clearly seen that participants "sometimes" $(n=63)$ and "often' $(n=62)$ used it as a digital dictionary, which most of foreign language learners often use as a supplementary tool. One of the reported activities that the participants carried out through mobile phones was utilizing it to check for correct pronunciation of words which they do not know (43\%=sometimes, $18,7 \%=$ often). The other significant finding was that the participants "sometimes" $(n=98)$ and "often" $(n=22)$ used the mobile phones to improve their listening comprehension ability by being exposed to the supported audio materials of authentic texts. The findings regarding the activities that were carried on mobile phone were also analyzed based on gender (Table 4).

Table 5. Activities Carried Out on Mobile Phone for Language Learning Purposes by Gender

\begin{tabular}{|c|c|c|c|c|c|c|c|}
\hline Activity & Gender & $\begin{array}{c}\text { Descriptive } \\
\text { Statistics } \\
\text { (ncl }\end{array}$ & Never & Sometimes & Often & Total & $\begin{array}{c}\text { Chi- } \\
\text { Square }\end{array}$ \\
\hline \multirow{4}{*}{1} & \multirow{2}{*}{ Female } & f & 52 & 58 & 43 & 153 & \multirow{4}{*}{$\begin{array}{c}\mathrm{X}^{2}=5.62 \\
\mathrm{df}=2 \\
\mathrm{p}=.060\end{array}$} \\
\hline & & $\%$ & 34.0 & 37.9 & 28.1 & 100.0 & \\
\hline & \multirow{2}{*}{ Male } & $f$ & 11 & 10 & 19 & 40 & \\
\hline & & $\%$ & 27.5 & 25.0 & 47.5 & 100.0 & \\
\hline \multirow{4}{*}{2} & \multirow{2}{*}{ Female } & $f$ & 56 & 81 & 16 & 153 & \multirow{4}{*}{$\begin{array}{c}x^{2}=1.54 \\
d f=2 \\
p=.462\end{array}$} \\
\hline & & $\%$ & 36.6 & 52.9 & 10.5 & 100.0 & \\
\hline & \multirow{2}{*}{ Male } & $f$ & 17 & 17 & 6 & 40 & \\
\hline & & $\%$ & 42.5 & 42.5 & 15.0 & 100.0 & \\
\hline \multirow{4}{*}{3} & \multirow{2}{*}{ Female } & $f$ & 62 & 62 & 29 & 153 & \multirow{4}{*}{$\begin{array}{c}x^{2}=2.0 \\
d f=2 \\
p=.366\end{array}$} \\
\hline & & $\%$ & 40.5 & 40.5 & 19.0 & 100.0 & \\
\hline & \multirow{2}{*}{ Male } & $f$ & 12 & 21 & 7 & 40 & \\
\hline & & $\%$ & 30.0 & 52.5 & 17.5 & 100.0 & \\
\hline \multirow{4}{*}{4} & \multirow{2}{*}{ Female } & $f$ & 86 & 56 & 11 & 153 & \multirow{4}{*}{$\begin{array}{c}X^{2}=1.03 \\
d f=2 \\
p=.598\end{array}$} \\
\hline & & $\%$ & 56.2 & 36.6 & 7.2 & 100.0 & \\
\hline & \multirow{2}{*}{ Male } & $f$ & 19 & 18 & 3 & 40 & \\
\hline & & $\%$ & 47.5 & 45.0 & 7.5 & 100.0 & \\
\hline \multirow{4}{*}{5} & \multirow{2}{*}{ Female } & $f$ & 40 & 70 & 43 & 153 & \multirow{4}{*}{$\begin{array}{c}x^{2}=.706 \\
d f=2 \\
p=.703\end{array}$} \\
\hline & & $\%$ & 26.1 & 45.8 & 28.1 & 100.0 & \\
\hline & \multirow{2}{*}{ Male } & $f$ & 13 & 16 & 11 & 40 & \\
\hline & & $\%$ & 32.5 & 40.0 & 27.5 & 100.0 & \\
\hline
\end{tabular}


When the results were analyzed by gender, it was found that $28.1 \%$ of the female participants "often" used digital dictionary software program on mobile phone. However, as for the male participants, this rate is much higher with the percentage of $47.5 \%$. What is significant is that almost half of the participants (male $=42.5 \%$, female $=52.9 \%$ ) preferred to listen to the audiosupported authentic materials on the mobile phone. A similar result was obtained from the activity that promotes the effective communication of the participants through correct pronunciation of the target language. It is reported that male participants $(52.5 \%)$ and female participants (40.5\%) "sometimes" checked the correct pronunciation of the words when they were not sure. There is no doubt that correct pronunciation is regarded as one of the crucial problems that learners frequently face. Thus, it is suggested that the use of digital dictionary at any stage of language learning needs to be encouraged, and this facility should be exploited as much as possible by both teachers and students. To download the required sources on the net via mobile phone does not always seem to be possible for the participants (Female=7.2\%, Male=7.5\%). The results show that there is no statistically significant difference between the use of mobile phones for educational purposes and communicative purposes $(p>0.05)$.

Table 6. Teachers' Encouragement to Use Mobile Phones to Support Language Learning

\begin{tabular}{lll}
\hline Responses & $\mathbf{f}$ & \% \\
\hline Yes & 88 & 45.6 \\
No & 105 & 54.4 \\
Total & 193 & 100.0 \\
\hline
\end{tabular}

The respondents were asked whether they got any encouragement from their teachers to support their language learning via mobile phones. It is true that using mobile phone effectively and successfully in the classroom is highly related to teachers' attitudes towards it. However, McNeal and Hooft (2006) maintain that despite the widespread popularity of mobile phones around the world, they have not been used widely in educational settings as some people feel reluctant. According to the results attained through the survey, it is seen that participants (54.4\%) were not encouraged enough to use mobile phone as an instructional tool by their teachers. The reasons for being reluctant to encourage learners to take advantage of this technological device in the classroom might derive from fear of abusing this tool or fear of disrupting traditional classroom set up. On the other hand, $45.6 \%$ of the participants stated that they were encouraged by their teachers. Educationally speaking, teachers' positive attitude towards using technology in foreign language teaching classroom facilitates successful learning (Huang \& Liaw, 2005).

The participants' views on the use of mobile phones in the classroom were analyzed and the findings are presented in Table 7. Specifically, they were asked if they favoured the use of mobile phone as an aid in completing schoolwork.

Table 7. Participants' Views on the Use of Mobile Phone

\begin{tabular}{|c|c|c|c|c|c|}
\hline \multicolumn{2}{|c|}{ Statement } & \multicolumn{2}{|l|}{ Yes } & \multirow{2}{*}{\multicolumn{2}{|c|}{$\begin{aligned} \text { No } \\
\%\end{aligned}$}} \\
\hline & & $\mathbf{n}$ & $\%$ & & \\
\hline 1 & $\begin{array}{l}\text { Do you think mobile phones will aid you in completing } \\
\text { schoolwork? }\end{array}$ & 130 & 67.4 & 63 & 32.6 \\
\hline 2 & $\begin{array}{l}\text { Would you like to use your mobile phone in the class as a } \\
\text { learning tool? }\end{array}$ & 128 & 66.3 & 65 & 33.7 \\
\hline
\end{tabular}


The results showed that $67.4 \%$ of the participants believed in the effectiveness of this tool in completing some language learning tasks. Being prospective English teachers, particpiants' propensity to use mobile phone in the class as a learning tool was investigated. 128 of the participants reported they would like to use mobile phones in class as an instructional tool. Table 8 compares the results of considering mobile phone as an aid to complete schoolwork with encouragement received by the teacher.

Table 8. Considering Mobile Phone as an Aid with Teachers' Encouragement for Its Use

\begin{tabular}{|l|c|l|l|l|c|}
\hline Learners Variables & \multicolumn{1}{|c|}{ YS } & \multicolumn{1}{|c|}{ No } & \multicolumn{1}{|c|}{ Total } & Chi-Square \\
\hline \multirow{2}{*}{$\begin{array}{l}\text { Learners encouraged to use } \\
\text { mobile phones }\end{array}$} & $\mathrm{f}$ & 62 & 26 & 88 & \multirow{2}{*}{$\mathrm{X}^{2}=.706$} \\
$\mathrm{nyyyyn}$ & $\%$ & 70.5 & 29.5 & 100.0 & $\begin{array}{c}\mathrm{df}=2 \\
\mathrm{p}=.401\end{array}$ \\
\cline { 2 - 5 } $\begin{array}{l}\text { Learners not encouraged to use } \\
\text { mobile phones }\end{array}$ & $\mathrm{f}$ & 68 & 37 & 105 & 100.0 \\
\cline { 2 - 5 }
\end{tabular}

Most of the participants reported that mobile phones would assist them in completing assigned tasks in the classroom. According to the results, it can be asserted that there is no statistically significant difference between the participants who are encouraged to use mobile phones in the classroom and those who think mobile phones will aid in completing schoolwork $(p>0.05)$.

Table 9. Willingness to Use Mobile Phone as an Aid with Teachers' Encouragement for Its Use

\begin{tabular}{|c|c|c|c|c|c|}
\hline Learners Variables & DS & Yes & No & Total & Chi-Square \\
\hline \multirow{2}{*}{$\begin{array}{l}\text { Learners encouraged to use } \\
\text { mobile phones }\end{array}$} & $f$ & 65 & 23 & 88 & \multirow{4}{*}{$\begin{array}{c}x^{2}=.412 \\
d f=2 \\
p=.041\end{array}$} \\
\hline & $\%$ & 73.9 & 26.1 & 100.0 & \\
\hline \multirow{2}{*}{$\begin{array}{l}\text { Learners not encouraged to use } \\
\text { mobile phones }\end{array}$} & $\mathrm{f}$ & 63 & 42 & 105 & \\
\hline & $\%$ & 60.0 & 40.0 & 100.0 & \\
\hline
\end{tabular}

A great number of the participants (73.9\%), who were encouraged to use mobile phones, stated that they would like to utilize mobile phones for educational purposes. On the other hand, $60 \%$ of those who were not encouraged to use mobile phones expressed that they wouldn't like to use it for educational purposes. The results above reveal that there is a statistically significant difference between those who are encouraged to use mobile phones in the classroom and those who are willing to use in the class $(p<0.05)$.

\section{Discussion}

It has been often stated that revolutionary changes in mobile technology has considerably contributed to revisions of traditional education models. The use of mobile phones and other mobile devices for educational purposes has received increasing attention (Chinnery, 2006). As Traxler (2009) indicates, the use of wireless, mobile, portable, and handheld devices are gradually increasing and diversifying across every sector of education. Ally (2009) claims that the twenty-first century learner will benefit from well-designed learning materials so that they can learn anywhere and at any time using mobile technology. Furthermore, using real-world resources for teaching and learning in the classroom can make education more meaningful and 
relevant to students (Mcneal \& Hooft, 2006, p.1). Students using mobile phones in learning become more successful than those using paper or web materials (Thornton \& Houser, 2005). Some students like the screen size limitations, which make the amount of content more manageable than that of other teaching materials (Chen, Hsieh, \& Kinshuk, 2008).

The related literature summarizes the services that mobile technologies offer to learners as follows: they are fast, effective, flexible, authentic, spontaneous, natural, motivating, portable, easy to use, and ubiquitous. Additionally, learners are provided with opportunities beyond the walls of the classroom, without restrictions of time and space. This study attempted to shed light on the use of the mobile phone as an instructional tool for foreign language teaching. In this respect, the participants were requested to share the extent to which they used mobile phones in and outside the walls of the English language teaching classroom. The results proved that more than half of the participants (58.5\%) preferred mobile phones for educational purposes. The study also investigated the types of activites that the participants carried out via mobile phone. According to the data obtained from the participants, sending SMS, and listening to music are the most frequently appreciated ones. It is seen that foreign language learners frequently use the SMS function of mobile phones, which can be utilized for foreign language learning purposes. To show the effectiveness of teaching through SMS, Saran and Seferoglu (2010) conducted a study with foreign language learners which proved that SMS is a great help for developing learners' vocabulary knowledge.

The results of the present study demonstrated that almost half of the participants $(47.5 \%$ of male participants) often used dictionaries on their mobile phones. Nowadays, it has been observed that very few foreign language learners carry dictionaries with them, while most prefer to use digital dictionaries on their phones. Regarding the use of mobile phones for listening purposes, a great number of participants stated that they sometimes $(n=98)$, listened to audio materials with accompanying texts, along with the responses of 98 (sometimes) and 22 (often). However, it is highly suggested that foreign language learners need to be exposed to authentic language as much as possible. A great majority of students $(n=119)$ responded that they generally ("sometimes" and "often") used it to check the pronunciation of the words. The results obtained from the survey are consistent with the suggestions that mobile phone can be used to practice pronunciation by recording audio materials (Thornton \& Houser, 2005). It is safe to say that one of the problematic areas that foreign language learners often face is mispronounced words, which can cause miscommunication and misunderstanding. As the research clearly indicates, the most common activity that the participants use is the digital dictionary that the mobile phone offers.

\section{Conclusions}

This study attempted to get a sense of how prospective English teachers are using their mobile phones both in and beyond the walls of the classrooms, along with their attitudes towards effective use in a forein language teaching context. This research proves that deploying mobile phone mediated language learning would promote foreign language learning, and this fact needs to be reviewed by foreign language teachers and course designers. Furthermore, it is widely admitted that it is not possible to adopt an innovative instructional material when it offers challenges for teachers or decision makers. Educationally speaking, the effective and successful use of any instructional tool is highly related to teachers' and learners' attitudes toward it. However, more specifically, the teacher in the classroom needs to be able to adopt this learning tool and its implications in order to meet the students' curiosity. In this vein, 
Mounier and Tangchuang (2010) note that the quality of the teaching-learning process depends on understanding the science concerning the relationship between knowledge, the teacher and the student. Additonally, King suggests that if we are to place the phenomenon of mobile learning within the context of the theories of instructional design, we need to "break down the walls to open up new spaces" (2006, p.171).

Utilizing mobile phones for prospective English teachers seems necessary in order to make the foreign language teaching environment more attractive and motivating. The use of technology has the potential not only to maintain attention but also to motivate learners to pay attention (Bester \& Brand, 2013). Considering the fact that mobile phones are becoming ubiquitous, are relevant to interactive learning, increase potential for distributed practice, and are suitable for encouraging classroom interactivity (Levy \& Kennedy, 2005), the foreign language teaching classroom should be refined (Anohina, 2005). As repeatedly cited above, mobile phones have several benefits for foreign language learners in developing correct pronunciation, promoting listening skills, getting feedback from teachers via SMS, delivering homework and tests via SMS and so forth. Having learners' positive attitudes (Markett, Sanchet, Weber, \& Tangney, 2006), promoting an active learning environment, and enabling an authentic learning community in the classroom are the other factors that mobile phone offers for the benefit of students. Furthermore, they are regarded as social tools that facilitate authentic and relevant communication and collaboration among learners (Thornton \& Houser, 2005). Uusing mobile phones as learning tools has many potential benefits for language learning and takes learning out of the classroom walls, often beyond the reach of the teacher (Kukulska-Hulme, 2009).

As mentioned above, the findings of this study cannot be overgenaralized for all prospective foreign languge teachers because the study has some limitations. First, the findings are limited to the questionnaire. Second, the study was limited to the participants of a university. Similar studies can be administered to large amount of participants through other research methods. Third, the study was conducted in the end of 2012. Since then, the number of the students owning mobile phones and the speed of internet access have increased. However, the results in this study suggest that mobile technology is new and needs to be explored further especially within the foreign language teaching context.

\section{References}

Acarturk, C. (2012). The use of barcode technology in education: An evaluation within the framework of cognitive science. Paper presented at the Academic Computing Conference 2012. February 1-2, 2012. Usak University, Usak.

Akbulut, Y. (2008). Exploration of the attitudes of freshman foreign language students toward using computers at a Turkish state university. Turkish Online Journal of Educational Technology, 7, 18-31.

Al Aemri, S.K.(2011). The use of mobile phones in learning English language by Sultan Qaboos University students: Practices, attitudes and challenges. Canadian Journal on Scientific \& Industrial Research, 2(3), 143-151.

Alexanders, B.(2004). Going nomadic: Mobile learning in higher education. Educause Review, 39(5), 28-35.

Ally, Mohammed. (Ed.) (2009). Mobile learning: Transforming the delivery of education and training. Edmonton, Canada: Athabasca University Press. 
Anohina, A. (2005). Analysis of the terminology used in the field of virtual learning. Journal of Educational Technology \& Society, 8(3), 91-102.

Attewell, J. (2005). Mobile technologies and learning: A technology update and m-learning project summary. London: Learning Skills Development Agency.

Attewell, J. \& Savill-Smith,C. (2005). Mobile learning anytime everywhere. London: Learning and Skills Development.

Basoglu, E. B. \& Akdemir, O. (2010). A comparison of undergraduate students' English vocabulary learning: Using mobile phones and flash cards. The Turkish Online Journal of Educational Technology, 9, 1-7.

Bayne, S. \& Ross, J. (2007). The 'digital native' and 'digital immigrant': A dangerous opposition. Paper presented at the Annual Conference of the Society for Research into Higher Education (SRHE). Retrieved on 12 April 2014 from http://www.malts.ed.ac.uk/staff/ sian/natives_final.pdf.

Bester, G. \& Brand, L. (2013). The effect of technology on learner attention and achievement in the classroom. South African Journal of Education, 33(2), 1-15.

Burston, J. (2011). Realizing the potential of mobile phone technology for language learning. The IALLT Journal. 41(2), 56-71.

Chen, NS., SW., Hsieh \& Kinshuk (2008). Effects of short-term memory and content representation type on mobile language learning. Language Learning and Technology, 12(3), 93-113.

Chinnery, M.G. (2006). Emerging technologies going to the MALL: Mobile assisted language learning. Language Learning \& Technology. 10(1), 9-16.

Cui, G. \& Wang, S. (2008). Adopting cell phones in EFL teaching and learning. Journal of Educational Technology Development and Exchange, 1(1), 68-80.

Cakir, H. (2011). Mobil ogrenmeye iliskin bir yazilim gelistirme ve degerlendirme. Cukurova Universitesi Egitim Fakultesi Dergisi, 2, 01-09.

Cavus, N. \& Ibrahim, D. (2009). m-Learning: An experiment in using SMS to support learning new English language words. British Journal of Educational Technology, 40(1), 78-91.

Cavus, N. \& Uzunboylu, H. (2009). Improving critical thinking skills in mobile learning. Procedia Social and Behavioral Sciences, 1, 434-438.

Cavus, N., Bicen, H. \& Akcil, U. (2008). The opinions of information technology students on using mobile learning. Paper presented at International Conference on Educational Sciences. Magosa, North Cyprus. Eastern Mediterranean University.

Chen, C. \& Chung, C. (2008). Personalized mobile English vocabulary learning system based on item response theory and learning memory cycle. Computers \& Education, 51(2), 624645.

Ducate, L. \& Lomicka, L. (2009). Podcasting: An effective tool for honing language students' pronunciation. Language Learning \& Technology, 13(3), 66-86

Edirisingha, P., Rizzi, C. Nie, M. \& Rothwell, L. (2007). Podcasting to provide teaching and learning support for an undergraduate module on English language and communication. Turkish Online Journal of Distance Education 8(3), 87-10 
Esit, O. (2011). Your verbal zone: An intelligent computer-assisted language learning program in support of Turkish learners. Computer Assisted Language Learning, 24(3), 211-232.

Friedman, A.D. (2012). How to collect and analyze qualitative data. In A. Mackey and S. M. Gass (Eds.), Researh methods in second language acqisition (pp.180-200). Hoboken, NJ: Wiley-Blackwell.

Hussein, M.O.M., \& Cronje, J.C. (2010). Defining Mobile Learning in the Higher Education Landscape. Educational Technology \& Society, 13(3), 12-21.

Gall, M. D., Gall, J. P., \& Borg, W. R. (2003). Educational research: An introduction (7th ed.). Boston, MA: Allyn and Bacon.

Geddes, S.J.(2004). Mobile learning in the 21st century: benefit to learners. Retrieved on 25 January 2014 from http://knowledgetree.flexiblelearning.net.au/edition06/ download/geddes.pdf

Huang, H.M. \& Liaw, S.S. (2005). Exploring users' attitudes and intentions toward the web as a survey tool. Computers in Human Behavior, 21(5), 729-743.

Hung, P.H., Hwang. G.J., Su, I.H. \& Lin, I.H. (2012). A concept-map integrated dynamic assessment system for improving ecology observation competences in mobile learning activities. The Turkish Online Journal of Educational Technology, 11(1), 10-19.

Keskin, O.N. \& Metcalf, D. (2011). The current perspectives, theories and practices of mobile learning. The Turkish Online Journal of Educational Technology, 10(2), 202-208.

Khanna, A. \& Singh, A. (2011). Efficacy of 'stop TB cricket': A mobile phone game for edutainment. Paper presented at the International Educational Technology Conference. Istanbul.

Kiernan, P. \& Aizawa, K.(2004). Cell phones in task based learning. Are cell phones useful language learning tools? ReCALL, 16(1), 71-84.

King, J. P. (2006). One hundred philosophers: A guide to world's greatest thinkers (2nd ed.). New York: Chartwell Books.

Kilickaya, F. (2009). The Effect of a Computer-Assisted Language Learning Course on PreService English Teachers' Practice Teaching. Educational Studies, 35(4), 437-448.

Krashen, S.D. (1985). The input hypothesis: Issues and implications. New York: Longman.

Kukulska-Hulme, A. \& Shield, L. (2006). Researching new and emerging technologies in language education. Unpublished presentation to internal Open University, UK INTELLECT research group.

Kukulska-Hulme, A.\& Shield, L. (2008). An overview of mobile assisted language learning: From content delivery to supported collaboration and interaction. ReCALL, 20(3), 271-289.

Kukulska-Hulme, A. (2009). Will mobile learning change language learning? European Journal for Computer Assisted Language Learning, 21(2), 157-165.

Kuzu, A., Cuhadar, C,. \& Akbulut, Y. (2007). Reflections of undergraduate students regarding PDA use for instructional purposes. Selçuk University Journal of Social Sciences Instute. 18, 359-365.

Levy, M. \& Kennedy, C. (2005). Learning Italian via mobile SMS. In A. Kukulska- Hulme and J. Traxler (Eds.), Mobile learning: A handbook for educators and trainers (pp. 76-83) London: Taylor \& Francis. 
Litchfield, A., Dyson, L., Lawrence, E. \& Zmijewska, A. (2007). Directions for m-learning research to enhance active learning. In ICT Providing choices for learners and learning. Proceedings ascilite Singapore 2007. Retrieved on 22 May 2014 from http://www. ascilite.org.au/conferences/ singapore07/procs/litchfield.pdf

Lu, M. (2008). Effectiveness of vocabulary learning via mobile phone. Journal of Computer Assisted Learning, 24(6), 515-525.

Mayisela, T. (2013). The potential use of mobile technology: enhancing accessibility and communication in a blended learning course. South African Journal of Education, 33(1), 1-18.

Markett, C., Sanchet, I.A., Weber, S. \& Tangney, B. (2006). Using short message service to encourage interactivity in the class room. Computers \& Education, 46(3), 280-293.

McConotha, D., Praul, M.\& Lynch, M.J. (2008). Mobile learning in higher education: An empirical assessment of a new educational tool. The Turkish Online Journal of Educational Technology, 7(3), 15-21.

McNeal, T. \& van't Hooft, M. (2006). Anywhere, anytime: Using mobile phones for learning. Journal of the Research Center for Educational Technology, 2(2), 24-31.

Meurant, R.C. (2007). Using Cell phones and SMS in second language pedagogy: A review with implications for their intentional use in the $\mathrm{L} 2$ classroom. Journal of Convergence Information Technology, 2(1), 98-106.

Mounier, A. \&Tangchuang, P. (2010). Education and knowledge in Thailand: The quality controversy ( $1^{\text {st }}$ ed.). Bangkok: Silkworm Books.

Nah, K.C., White, P.\& Sussex, R. (2008). The potential of using a mobile phone to access the internet for learning EFL listening skills within a Korean context. European Association for Computer Assisted Language Learning, 20(3), 331-347.

Naismith, L., Lonsdale, P., Vavoula, G. \& Sharples, M. (2004). Teaching and learning with mobile technologies-case studies. Retrieved on 20 January 2014 from http://www. futurelab.org.uk

Oblinger, D. (2003). Boomers, gen-Xers and millennials: Understanding the new students.EDUCAUSE Review, July/August 2003. Retrieved on 22 May 2014 from http://www.educause.edu/ir/library/pdf/erm0342.pdf.

Odabasi, H. (2009, October). Mobile learning and the mobile library. Paper presented at the Symposium on the Information Age of Being: Opportunities and Threats. Yeditepe University, Istanbul. 1-2 October, 2009.

Oelofse, C.H. (2008). The Learner profile of a teenage cell phone user. Master of education, University of Pretoria, Pretoria. Retrieved on 20 January 2014 from http://upetd.up.ac. za/thesis/available/utd-07102009-160407/unrestricted/

Prensky, M. (2007). Digital game-based learning. St. Paul, MN: Paragon House.

Reinders, H. \& Cho, M.Y. (2010). Extensive listening practice and in put enhancement using mobile phones: Encouraging out-of-class learning with mobile phones. Teaching English as a Second or Foreign Language, 14(2). Retrieved on 22 May 2014 from http://www. tesl- ej. org /wordpress/issues/volume14/ej54/ej54m2/ 
Saran, M., Cagiltay, K. \& Seferoglu, G. (2008). Use of mobile phones in language learning: Developing effective instructional materials. 5th International Conference on Wireless, Mobile and Ubiquitous Technologies in Education-WMUTE2008.

Saran, M., Cagiltay, K., \& Seferoglu, G. (2007). Technology enhanced learning in foreign language education: The use of mobile phones. Paper presented at the annual convention of the Association for Educational Communications and Technology (AECT). Anaheim, California, USA.

Saran, M.\& Seferoğlu, G. (2010). Supporting foreign language vocabulary learning through multimedia messages via mobile phones. Hacettepe University Journal of the Faculty of Education, 38(1), 252-266.

Sengel, E., Oncu, S., \& Goktalay. (2014). Achievement in Language Learning: Effects of Various Computer Assisted Activities and Computer Literacy. Hacettepe University Journal of the Faculty of Education, 29(1), 267-279.

So, S. (2009). The development of a SMS-based teaching and learning system. Journal of Educational Technology Development and Exchange, 2(1), 113-124.

Song, Y. \& Fox, R. (2005). Integrating m-technology into web-based ESL vocabulary learning for working adult learners. Proceedings of the 2nd IEEE international workshop on wireless and mobile technologies education. Jhongli, Taiwan. IEEE Computer Society.

Stockwell, G. (2010).Using mobile phones for vocabulary activities: examining the effect of the platform. Language Learning \& Technology, 14(2), 95-110.

Tai, Y. Ting \& Y. L. (2011). Adoption of mobile technology for language learning: Teacher attitudes and challenges. The JaltCall Journal, 7(1), 3-18.

Thornton, P. \& Houser, C. (2005). Using mobile phones in English education in Japan. Journal of Computer Assisted Learning, 21(3), 217-228.

Traxler, J. (2009). Current state of mobile-learning. In M. Ally (Ed.), Mobile Learning: Transforming the delivery of education and training (pp. 9-25). Edmonton, Canada: Athabasca University Press.

Uzunboylu, H. \& Ozdamli, F. (2011). Teacher perception for m-learning: Scale development and teachers' perceptions. Journal of Computer Assisted Learning, 27(6), 544-556.

Wang, M., Shen, R., Novak, D. \& Pan, X. (2009). The impact of mobile learning on students' learning behaviours and performance: Report from a large blended classroom. British Journal of Educational Technology, 40(4), 673-695.

Wu, W., Wu, Y. J., Chen, C., Kao, H., Lin, C., \& Huang, S. (2012). Review of trends from mobile learning studies: A meta-analysis. Computers \& Education, 59(2), 817-827.

Zhang, H., Song, W. \& Burston, J. (2011). Reexamining the effectiveness of vocabulary learning via mobile phones. The Turkish Online Journal of Educational Technology, 10(3), 203214.

Correspondence: Ismail Cakir, Associate Professor, Department of Foreign Languages Teaching, Faculty of Education, Erciyes University, Kayseri, Turkey 